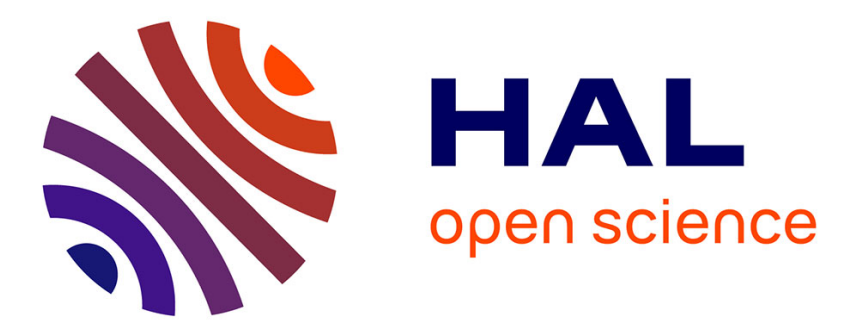

\title{
Introduction: Hydrogen isotopes as environmental recorders
}

\author{
Valery T. Terwilliger, Jérémy Jacob
}

\section{To cite this version:}

Valery T. Terwilliger, Jérémy Jacob. Introduction: Hydrogen isotopes as environmental recorders. Geochimica et Cosmochimica Acta, 2013, 111, pp.1-4. 10.1016/j.gca.2013.02.001 . insu-00787432

\section{HAL Id: insu-00787432 \\ https://hal-insu.archives-ouvertes.fr/insu-00787432}

Submitted on 12 Feb 2013

HAL is a multi-disciplinary open access archive for the deposit and dissemination of scientific research documents, whether they are published or not. The documents may come from teaching and research institutions in France or abroad, or from public or private research centers.
L'archive ouverte pluridisciplinaire HAL, est destinée au dépôt et à la diffusion de documents scientifiques de niveau recherche, publiés ou non, émanant des établissements d'enseignement et de recherche français ou étrangers, des laboratoires publics ou privés. 
Introduction: Hydrogen isotopes as environmental recorders

Valery J. Terwilliger ${ }^{\mathrm{a}, \mathrm{b}, \mathrm{c}, \mathrm{d}}$, Jérémy Jacob ${ }^{\mathrm{c}, \mathrm{d}, \mathrm{e}}$

${ }^{a}$ LE STUDIUM ${ }^{\circledR}$, Loire Valley Institute for Advanced Studies, 3D avenue de la Recherche Scientifique 45071, Orléans, France.

${ }^{\mathrm{b}}$ Department of Geography, University of Kansas, Lawrence, KS 66045, USA.

' Université d'Orléans, Institut des Sciences de la Terre d'Orléans (ISTO), UMR 7327, 45071, Orléans, France.

${ }^{\mathrm{d}}$ CNRS/INSU, ISTO, UMR 7327, 45071 Orléans, France.

e BRGM, ISTO, UMR 7327, BP 36009, 45060 Orléans, France.

Interpreting past environmental conditions is often a prerequisite for advancing research in areas as fundamental and diverse as the evolution of life and the consequences of climatic change for the future of societies. Stable hydrogen isotopic ratio $(\mathrm{D} / \mathrm{H})$ analyses of organic compounds preserved in natural archives such as soils and sediments, are finding increasing applications for revealing past hydrological conditions (Eglinton and Eglinton, 2008; Sachse et al., 2012). At the crux of these applications is a physical relationship between the $\mathrm{D} / \mathrm{H}$ of meteoric water and climate caused by the effects of temperature and availability of cloud water on the precise distribution of isotopes in precipitation (Dansgaard, 1964; Yurtsever, 1975; Gat, 1980; Vimeux et al., 1999). The D/H of organic compounds contains information about climate because the original source of hydrogen in any organic compound can ultimately be traced to precipitation (Estep and Hoering, 1980; Estep and Dabrowski 1980; Sternberg, 1989).

Although initial climatic records inferred from $\mathrm{D} / \mathrm{H}$ of degradation-resistant compounds have been promising (Huang et al., 2002; Schefuss et al., 2005) challenges remain in order to attain the most comprehensive and highest resolution interpretations of hydrology from $\mathrm{D} / \mathrm{H}$ of organic compounds. First, geography has a large underlying influence on the precise climatic conditions shaping the $\mathrm{D} / \mathrm{H}$ of atmospheric moisture and the precipitation from it. Most atmospheric water originates at tropical latitudes and there the $\mathrm{D} / \mathrm{H}$ of its precipitation reflects rainfall amount rather than temperature (Rozanski et al., 1993). In contrast --through its role in the Rayleigh distillation-like effects on the $\mathrm{D} / \mathrm{H}$ of residual cloud mass - temperature shapes the 
$\mathrm{D} / \mathrm{H}$ of precipitation over higher latitudes (Alley and Cuffey, 2001). Additional geographic factors such as elevation, distance from ocean water, and proportion of global water in ice also affect D/H of precipitation (Siddall and Masson-Delmotte 2012).

A second factor affecting the resolution with which hydrological conditions can be interpreted from $\mathrm{D} / \mathrm{H}$ of organic materials is the hydrogen fractionations that occur between precipitation and the water that is used in photosynthesis. Evaporation forces cause these fractionations to precipitation when it reaches the soil and --following uptake of soil water into plants-- during transpiration in the leaves where much of photosynthesis will take place globally (Jackson et al., 1999; Tang and Feng, 2001; Ogee et al., 2007). Hydrogen isotopic fractionations in water are affected by humidity (Craig and Gordon, 1965; Dongmann et al., 1974 ) and result in variations in $\mathrm{D} / \mathrm{H}$ in water sources to and within photosynthesizing organisms receiving isotopically identical precipitation.

A third and very actively studied area consists of quantifying the biological fractionations between the hydrogen of water used in photosynthesis and that of a biochemical of interest (Kennedy and Krouse, 1990; Yakir, 1992; Mclnerney et al., 2011; Peters et al., 2012). The mechanics of the total fractionation of hydrogen during photosynthesis is less understood than for carbon. Nevertheless, that fractionation is probably nearly constant. Metabolic reactions cause further fractionations during steps leading to the synthesis of specific organic compounds. Consistently large differences in metabolic fractionations have been found between specific lipid compounds among bacterial groups (Zhang et al., 2009). Large differences in $\mathrm{D} / \mathrm{H}$ values of carbohydrates between plants with Crassulacean Acid Metabolism (CAM) and with other photosynthetic pathways have long been established but the $\mathrm{D} / \mathrm{H}$ of their lipids were not thought to vary as a function of photosynthetic type (Sternberg, 1989). Recent studies suggest that hydrogen isotopic fractionations may differ between plants with $\mathrm{C}_{3}, \mathrm{C}_{4}$, and CAM photosynthetic pathways (Feakins and Sessions, 2010; McInerney et al., 2011). A more quantitative understanding of the biological causes of hydrogen isotopic fractionations would clearly lead not only to more defined hydrological interpretations from organic materials in all taxa but to knowledge of biological/environmental interactions as well.

Although not comprehensive, the aforementioned categories of factors point to one more challenge to the fullest use of $\mathrm{D} / \mathrm{H}$ analyses of archived organic compounds to infer environmental conditions. Achieving this objective requires productive communication amongst 
researchers from the full range of disciplines that can inform the use of stable hydrogen isotopic analyses for inferring environmental conditions.

We have taken advantage of an unusual opportunity to foster that communication via two avenues. The first avenue was the organization of a topical (100 participants), international conference on Hydrogen Isotopes as Environmental Recorders (http://lestudium.cnrsorleans.fr/hydrogen.html). The conference was supported by LE STUDIUM ${ }^{\circledR}$ Loire Valley Institute for Advanced Studies was held at the Centre National de Recherche Scientifique and Université d'Orléans campus in Orléans France on 15-16 September 2011. LE STUDIUM ${ }^{\circledR}$ is the principal provider of fellowships to foreign scholars visiting research institutes in the Centre region of France and provides support for small, appropriately individualized international conferences. Attendees to this conference represented diverse fields including organic geochemistry, physics, plant and animal physiology, geology, geography, and atmospheric chemistry. The second avenue is this collection that further the understanding of environmental information that can be obtained from hydrogen isotopic analyses. The authors of the papers herein include not only conference participants but others motivated to contribute to this theme.

Both the conference presentations and the papers in this issue contribute to addressing the following questions.

I. What information about environmental phenomena can $\mathrm{D} / \mathrm{H}$ of inorganic (especially water) and organic (especially specific compounds) substances provide?

II. What do we still need to know to obtain the best information about environment from $\mathrm{D} / \mathrm{H}$ of inorganic and organic substances?

III. What approaches can we share in order to best resolve the controversies about using hydrogen isotopic analyses to obtain information about environmental phenomena?

Presentations at the conference focused on the following themes:

1) environmental controls on the distribution of hydrogen isotopes in atmospheric, surface and groundwaters,

2) $\mathrm{D} / \mathrm{H}$ in plant water,

3) source water, biological, and temporal effects on $\mathrm{D} / \mathrm{H}$ of recalcitrant lipids,

4) mechanisms of natural hydrogen isotopic fractionations in fatty acids, and

5) environmental and biological interpretations on scales ranging from microbial to the solar system from $\mathrm{D} / \mathrm{H}$ in organic molecules. 
Nolan and Bindeman make a novel contribution to theme 1) via their experimental approach to establishing roles of temperature and hence implications for evaluating paleoclimate from $\mathrm{D} / \mathrm{H}$ of hydrous minerals and volcanic glass. Lixin Wang et al.'s use of the $\mathrm{D} / \mathrm{H}$ of atmospheric waters in an approach that quantifies the contributions of plant transpiration to the total evapotranspiration of an area bridges both themes 1) and 2).

Four papers herein use $\mathrm{D} / \mathrm{H}$ analyses of plant waters to improve knowledge of themes 3 ) and 5) in tandem. In two papers, Kahmen et al.'s direct analyses of plant water D/H in field and controlled environmental settings contribute to quantifying effects of transpiration on $\mathrm{D} / \mathrm{H}$ of nalkanes in leaf wax. Tipple and Pagani incorporate tree-water D/H into an improved understanding of the extent to which $\mathrm{D} / \mathrm{H}$ of $\mathrm{n}$-alkanes in soils integrate environmental influences on their plant sources. Eley et al.'s analyses of leaf waters in plants with different forms and photosynthetic pathways inform their conclusions about the importance of biochemical differences on the $\mathrm{D} / \mathrm{H}$ of $\mathrm{n}$-alkyl lipids derived from leaf waxes.

Environmental interpretations from $\mathrm{D} / \mathrm{H}$ of animal-derived substances is a particular research frontier. Chikaraishi's comparison of $\mathrm{D} / \mathrm{H}$ in long-chain $n$-alkanes and $n$-alkenes between insects, $\mathrm{C}_{3}$ and $\mathrm{C}_{4}$ plants common to their field sites and its implications for interpretations made from analyses of these compounds in soils and sediments contribute to themes 3) and 5). Three papers contribute to themes 3) and 5) by examining relationships of climate on geographic gradients to the $\mathrm{D} / \mathrm{H}$ of animal-derived substances. Topalov et al. expand theme 3) to comprehensively evaluate relationships of $\mathrm{D} / \mathrm{H}$ in bone collagen to $\mathrm{D} / \mathrm{H}$ of meteoric water and to dietary changes from mother's milk to adult foods. Ehtesham et al. demonstrate that production locations of milk can be tracked via the $\mathrm{D} / \mathrm{H}$ of the milk's fatty acids. Pitter et al. demonstrate a potential for interpreting paleoprecipitation trends from the $\mathrm{D} / \mathrm{H}$ in ruminant adipose- and milk-derived fatty acids obtained from known archeological contexts.

Four contributions to theme 5) in this issue quantify or quantitatively consider known possible influences in addition to the $\mathrm{D} / \mathrm{H}$ of source water when interpreting $\mathrm{D} / \mathrm{H}$ of organic substances. DeBond et al. offer an approach to determining isotopic shifts in a bulk organic source caused by decomposition from the D/H of that source's cellulose, hemicellulose, and lignin components. Yiming Wang et al. and Terwilliger et al. propose different approaches to account for effects of vegetation type on interpretations from $\mathrm{D} / \mathrm{H}$ of $\mathrm{n}$-alkyl lipids in soils and sediments for paleoclimate records. Van der Meer et al. demonstrate that interpretations of sea 
surface salinity from $\mathrm{D} / \mathrm{H}$ of alkenones of haptophyte algae are more robust if alkenones of a specific carbon chain length (in this case $\mathrm{C}_{37}$ ) are analyzed ensemble rather than by individual components.

Clearly, environmental interpretations from D/H of organic compounds benefit from knowledge of physical, chemical, and biological processes shaping hydrogen fractionations. Rather than treating this diversity of the factors as noise that constrains interpretations, this issue demonstrates how interdisciplinary communication can improve those interpretations.

\section{Acknowledgements-}

We wish to thank Frank A. Podosek for his early enthusiastic commitment to the concept of this issue and for his helpful suggestions for maximizing its quality and impact. We are grateful to Marc Norman for gracefully taking on the editorial burdens in medias res of bringing this issue to fruition. The conference from which this issue is an outgrowth would not have been possible had Paul Vigny not put his creative ideas for productive exchange of knowledge among international scholars into practice via Le STUDIUM ${ }^{\circledR}$ Loire Valley Institute for Advanced Studies. Last but not least, we thank the conference participants and the authors of this issue for creating a model for productive communication and problem solving of the contentious areas surrounding the interpretation of environmental conditions from stable hydrogen isotopic composition of materials whose original hydrogen sources can be traced to meteoric water.

\section{REFERENCES}

Alley R. B. and Cuffey K. M. (2001) Oxygen- and hydrogen- isotopic ratios of water in precipitation: beyond paleothermometry. Reviews in Mineralogy and Geochemistry 43, 527-553.

Craig H. and Gordon L. I. (1965) Deuterium and oxygen-18 variations in the ocean and marine atmosphere. In Stable Isotopes in Oceanographic Studies and Paleotemperatures. (ed. E. Tongiorgi). Proceedings of the Third Spoletto Conference, pp. 1-122. 
Dansgaard W. (1964) Stable isotopes in precipitation. Tellus 5, 461-469.

Dongmann G., Nürnberg H. W., Förstel H. and Wagener K. (1974) On the enrichment of $\mathrm{H}_{2}{ }^{18} \mathrm{O}$ in the leaves of transpiring plants. Radiation and Environmental Biophysics 11, 41-52.

Eglinton T. I. and Eglinton G. (2008) Molecular proxies for paleoclimatology. Earth and Planetary Science Letters 275, 1-16.

Estep M. F. and Dabrowski H. (1980) Tracing food webs with stable hydrogen isotopes. Science 209, 1537-1538.

Estep M. F., Hoering T. C. (1980) Biogeochemistry of the stable hydrogen isotopes. Geochimica et Cosmochimica Acta 44, 1197-1206.

Feakins S. J. and Sessions A. L. (2010) Crassulacean acid metabolism influences D/H ratio of leaf wax in succulent plants. Organic Geochemistry 41, 1269-1276.

Gat J. R. (1980) The isotopes of hydrogen and oxygen in precipitation. In Handbook of Environmental Isotope Geochemistry, (eds. P. Fritz and J. Ch. Fontes). Elsevier, Amsterdam, vol. 1. pp. 21-47.

Huang Y. S, Shuman B., Wang Y. and Webb T. (2002) Hydrogen isotope ratios of palmitic acid in lacustrine sediments record late Quaternary climate variations. Geology 30, 11031006.

Kennedy B. V. and Krouse H. R. (1990) Isotope fractionation by plants and animals: implications for nutrition research. Canadian Journal of Physiological Pharmacology 68, 960972.

McInerney F. A., Helliker B. R. and Freeman K. H. (2011) Hydrogen isotope ratios of leaf wax $n$ alkanes in grasses are insensitive to transpiration. Geochimica et Cosmochimica Acta 75, 541-554. 
Ogee J., Cuntz M., Peylin P. and Bariac T. (2007) Non-steady-state, non-uniform transpiration rate and leaf anatomy effects on the progressive stable isotope enrichment of leaf water along monocot leaves. Plant, Cell and Environment 30, 367-387.

Peters J. M., Wolf N., Stricker C. A., Collier T. R., Martínez del Rio C. (2012) Effects of trophic level and metamorphosis on discrimination of hydrogen isotopes in a plant-herbivore system. PLoS One 7, e32744. doi:10.1371/journal.pone.0032744.

Rozanski K., Araguás-Araguás L. and Gonfiantini R. (1993) Isotopic patterns in modern global precipitation. In Climate Change in Continental Isotopic Records. Geophys Monogr Ser, (eds. P. K. Swart, K. C. Lohmann, J. McKenzie and S. Savin). AGU, Washington, D. C., vol. 78. pp. 1-36.

Sachse D., Billault I., Bowen G. J., Chikaraishi Y., Dawson T. E., Feakins S. J., Freeman K. H., Magill C. R., Mclnerney F. A., van der Meer B. T. J., Polissar P., Robins R. J., Sachs J. P., Schmidt H.-L., Sessions A. L., White J. W. C., West J. B. and Kahmen A. (2012) Molecular paleohydrology: interpreting the hydrogen-isotopic composition of lipid biomarkers from photosynthesizing organisms. Annual Review of Earth and Planetary Sciences 40, 221-249.

Schefuss E., Schouten S., Schneider F. F. (2005) Climatic controls on central African hydrology during the past 20,000 years. Nature $437,1003-1006$.

Siddall M., Milne G. A., Masson-Delmotte V. (2012) Uncertainties in elevation changes and their impact on Antarctic temperature records since the end of the last glacial period. Earth and Planetary Science Letters 315-316, 12-23.

Sternberg L. S. L. (1989) Oxygen and hydrogen isotope ratios in plant cellulose: mechanisms and applications. In Stable Isotopes in Ecological Research. (eds. P. W. Rundel, J. R. Ehleringer and K. A. Nagy) Springer, New York, pp. 124-141.

Tang K. and Feng X. (2001) The effect of soil hydrology on the oxygen and hydrogen isotopic compositions of plants' source water. Earth and Planetary Science Letters 185, 355-367. 
Vimeux F., Masson V., Jouzel J., Stievenard M. and Petit J. R. (1999) Glacial-interglacial changes in ocean surface conditions in the southern hemisphere. Nature 398, 410-413.

Yurtsever Y. (1975) Worldwide survey of stable isotopes in precipitation. Report Section Isotope Hydrology. International Atomic Energy Association, Vienna.

Yakir, D. (1992) Variations in the natural abundance of oxygen-18 and deuterium in plant carbohydrates. Plant, Cell and Environment 15, 1005-1020.

Zhang X., Gillespie A. L. and Sessions A. (2009) Large D/H variations in bacterial lipids reflect central metabolic pathways. Proceedings of the National Academy of Sciences 106, 12580-12586. 